\title{
Common Acute Lymphoblastic Leukemia Antigen Expressed on Leukemia and Melanoma Cell Lines Has Neutral Endopeptidase Activity
}

\author{
C. Victor Jongeneel, “ Elizabeth J. Quackenbush, ${ }^{\ddagger}$ Pierre Ronco, ${ }^{\S}$ Pierre Verroust, ${ }^{\S}$ Stefan Carrel, ${ }^{\star}$ and Michelle Letarte ${ }^{\ddagger}$ \\ ${ }^{*}$ Ludwig Institute for Cancer Research, Lausanne Branch, CH-1066 Epalinges, Switzerland; ${ }^{\ddagger}$ Department of Immunology, Hospital for \\ Sick Children and University of Toronto, Toronto, Canada M5G1X8; ${ }^{\S}$ Institut National de la Santé et de la Recherche Médicale U64, \\ Hopital Tenon, 75020 Paris, France
}

\begin{abstract}
We have previously reported that the amino acid sequence of the common acute lymphoblastic leukemia antigen (CALLA, CD10) translated from a normal human kidney cDNA clone is identical to that of neutral endopeptidase (NEP, EC 3.4.24.11). In this study, we show that by flow cytometry, a monoclonal antibody (135A3) produced against rabbit NEP reacted selectively with leukemia and melanoma cell lines expressing CALLA on their surface. A glycoprotein of apparent $M_{r} 100,000$ was immunoprecipitated from surface labeled NALM-1 leukemia or Mel-1477 melanoma cells with monoclonal antibodies to NEP (135A3) or CALLA (44C10). mRNAs hybridizing to a NEP-specific probe were present in $\mathrm{CALLA}^{+}$leukemia and melanoma cell lines, but absent from CALLA $^{-}$lines. NEP enzymatic activity was detected on intact cells from CALLA ${ }^{+}$lines, but not $\mathrm{CALLA}^{-}$lines. The activity was blocked by two selective inhibitors of NEP, thiorphan and phosphoramidon. CALLA antigen purified from the NALM-6 leukemic cell line by affinity to 44C10-IgG Sepharose retained a peptidase activity that was completely blocked by thiorphan and phosphoramidon. Thus the CALLA antigen present at the surface of leukemia and melanoma cell lines is an enzymatically active neutral endopeptidase.
\end{abstract}

\section{Introduction}

The common acute lymphoblastic leukemia antigen (CALLA; $\mathrm{CD} 10)^{1}$ is a membrane glycoprotein of $M_{\mathrm{r}} 95,000-100,000$ (1-6) that was first identified on lymphoblasts of patients with the common (pre-B) type of acute lymphoblastic leukemia (ALL) $(1,2,7,8)$. While CALLA is not expressed on normal $\mathrm{T}$

Address reprint requests to Dr. Letarte, Department of Immunology, Hospital for Sick Children, 555 University Avenue, Toronto, Ontario, M5G 1X8 Canada.

Received for publication 25 August 1988 and in revised form 11 November 1988.

1. Abbreviations used in this paper: ALL, acute lymphoblastic leukemia; CALLA, common acute lymphoblastic leukemia antigen; DAGNPG, dansyl-D-Ala-Gly-Phe $\left(p \mathrm{NO}_{2}\right)$-Gly; NEP, neutral endopeptidase.

J. Clin. Invest.

(C) The American Society for Clinical Investigation, Inc.

0021-9738/89/02/0713/05 \$2.00

Volume 83, February 1989, 713-717 and B lymphocytes and on monocytes, it is found on lymphoid precursors in fetal liver and bone marrow, and on normal granulocytes (9-11). It is also present on several nonhemopoietic tissues: in kidney, on the brush border of proximal tubules and on glomerular epithelium $(1,3,12,13)$; in adult breast, on myoepithelial cells (12); and in fetal small intestine, on the microvillar epithelium (12).

We have recently isolated a cDNA clone coding for CALLA from a human kidney library (14). The cDNA sequence can be translated into a protein of 749 amino acids, whose sequence is identical to that reported for CALLA from the NALM-6 leukemic cell line (15), and to that of the recently cloned human neutral endopeptidase (NEP, EC 3.4.24.11) $(14,16)$. This enzyme, initially purified from rabbit renal brush border $(17,18)$, is a membrane-bound zinc-containing metallopeptidase with a specificity related to that of thermolysin (17-21). The presence of NEP has been detected by its enzymatic activity and/or with antibodies in several normal tissues (including brain) in rat, rabbit, pig, and man (16-30). NEP has its active site exposed to the extracellular environment, and is capable of hydrolyzing a number of peptides. NEP activity can be distinguished from that of other peptidases by its selective inhibition by the synthetic peptides thiorphan and phosphoramidon (17-19, 23, 27-29). Known natural substrates of NEP include angiotensins, enkephalins, atrial natriuretic peptide, substance $P$, chemotactic peptide, and several other biologically active peptides $(17-19,28,29,31)$.

NEP activity has never been reported in malignant cells. On the other hand, CALLA is found on lymphoblastic leukemias, on certain lymphomas, and on melanomas and glioma cell lines $(1,5,7,8,32)$. We show in the current study that CALLA expressed on malignant cells expresses antigenic determinants of neutral endopeptidase and is enzymatically active.

\section{Methods}

Cell lines. The pre-B ALL cell lines NALM-1 (5) and NALM-6 (33), the T-ALL cell lines Jurkat and HSB-2 (34), the Burkitt's lymphoma line Daudi (5), and the melanoma lines Mel-1477, LSD22 (35), and A375 (34) were grown in RPMI 1640 medium supplemented with $10 \%$ FCS.

Monoclonal antibodies. MAb 44C10 (IgG2b, $\kappa$ ), 44G4 (IgG1, $\kappa$ ), and 44E3 $(\operatorname{IgG} 1, \kappa)$ were produced by immunization of Balb/c mice with the pre-B ALL cell line $\mathrm{HOON}$; $44 \mathrm{C} 10$ was shown to react with CALLA antigen (36), while the two others were used as negative controls. MAb 135A3 (IgG2b) was derived by immunization of Balb/c mice with tubular cells from rabbit renal cortex as described for pre- 
vious MAb (25). IgG fractions were purified using standard procedures $(23,36)$. For competitive antibody binding studies (37), $44 \mathrm{C} 10 \mathrm{IgG}$ was radiolabeled with $\mathrm{Na}^{125} \mathrm{I}$ using Iodogen (Pierce Chemical Co., Rockford, IL).

Cell surface-labeling and immunoprecipitation. Cells from the NALM-1 or Mel-1477 lines $\left(1 \times 10^{7}\right)$ were labeled with $\mathrm{Na}^{125}$ I using the lactoperoxidase/glucose oxidase-catalyzed reaction, and surface antigens were immunoprecipitated from a $1 \%$ Genapol X-080 (Calbiochem, Lucerne, Switzerland) extract as described earlier (38).

Purification of CALLA antigen from NALM-6 cells. NALM-6 cells $\left(3 \times 10^{9}\right)$ were harvested, washed three times with PBS and solubilized at $2 \times 10^{7}$ cells $/ \mathrm{ml}$ in $0.05 \mathrm{M}$ Tris, $\mathrm{pH} 7.0,0.15 \mathrm{M} \mathrm{NaCl}, 0.5 \%$ Triton $\mathrm{X}-100,1 \mathrm{mM}$ PMSF for $2 \mathrm{~h}$ at $4^{\circ} \mathrm{C}$. The soluble extract $(100,000 \mathrm{~g})$ was incubated with $5 \mathrm{ml}$ of control nonimmune murine IgG-Sepharose beads $(2 \mathrm{mg} \mathrm{IgG} / \mathrm{ml})$ for $16 \mathrm{~h}$, and with $7 \mathrm{ml}$ of $44 \mathrm{C} 10 \mathrm{IgG}-S e p h a r o s e$ beads for $24 \mathrm{~h}$ at $4^{\circ} \mathrm{C}$. The beads were washed, and the antigen was eluted with $0.05 \mathrm{M}$ diethylamine, $\mathrm{pH} 11.2,0.3 \%$ deoxycholate. The antigen preparation and the beads were immediately neutralized with $0.5 \mathrm{M}$ Tris, $\mathrm{pH} 6.8$. The $44 \mathrm{C} 10$ antigen preparation was concentrated by ultrafiltration and frozen in aliquots at $-70^{\circ} \mathrm{C}$.

RNA preparation and Northern blot analysis. Total RNA was isolated from freshly harvested cells by the acid guanidinium thiocyanate-phenolchloroform extraction procedure (39). Northern blots were probed with a $1.6 \mathrm{~kb}$ Eco RI fragment of kidney-derived CALLA cDNA, which we know codes for NEP (14).

Fluorimetric assay of NEP activity. Assays were performed essentially as described (40), using the synthetic substrate dansyl-D-AlaGly-Phe $\left(p \mathrm{NO}_{2}\right)$-Gly (DAGNPG; Sigma Chemical Co., St Louis, MO). Cells were washed three times in PBS, once in Pipes buffer ( $50 \mathrm{mM}$ Pipes, pH 6.4, $150 \mathrm{mM} \mathrm{NaCl}$ ), and resuspended in Pipes buffer at 4 $\times 10^{7} \mathrm{ml}^{-1}$. For each assay, $2 \times 10^{6}$ cells were incubated in a $0.1-\mathrm{ml}$ volume with $50 \mu \mathrm{M}$ substrate in Pipes buffer at $37^{\circ} \mathrm{C}$. The reaction was stopped by adding $0.4 \mathrm{ml}$ of ice-cold Pipes buffer containing $5 \mathrm{mM}$ EDTA, the cells were pelleted for $5 \mathrm{~min}$ at $10,000 \mathrm{~g}$, and the fluorescence of the supernatant was measured in a (model LS-5; Perkin-Elmer Co., Norwalk, CT) luminescence spectrometer, using an excitation slit width of $5 \mathrm{~nm}$ at a wavelength of $342 \mathrm{~nm}$ and an emission slit of $10 \mathrm{~nm}$ at $562 \mathrm{~nm}$.

To measure the activity of the purified CALLA preparation, the buffer was supplemented with $0.1 \%$ Genapol X-080 and with $50 \mu \mathrm{M}$ $\mathrm{Zn}$ acetate as indicated. At increasing reaction times $(0-120 \mathrm{~min})$, $0.1-\mathrm{ml}$ aliquots were quenched in ice-cold Pipes buffer containing 5 mM EDTA, centrifuged to remove the fine precipitate formed in the reaction, and processed as above. A doubling in the initial fluorescence intensity corresponds to the hydrolysis of $20 \%$ of the substrate (40).

\section{Results}

Reactivity of a monoclonal antibody to NEP with CALLA-positive tumor cells. In a recent paper, we demonstrated that the sequence of a CALLA cDNA clone is identical to that coding for human neutral endopeptidase (14). The sequences of human, rabbit and rat NEP are $95 \%$ identical $(14,16,20,22)$. Therefore, we investigated the reactivity of CALLA ${ }^{+}$cells with MAb 135A3 (26), an antibody directed against rabbit NEP, which cross-reacts with human NEP.

The fluorescence histograms shown in Fig. 1 demonstrate that MAb 135A3 reacted with two $\mathrm{CALLA}^{+}$pre-B ALL cell lines, NALM-1 and NALM-6, but not with two CALLA-TALL cell lines, Jurkat and HSB-2. The CALLA ${ }^{+}$melanoma cell line Mel-1477 was also stained by MAb 135A3, but to a lesser degree than the pre-B leukemic lines. The LSD22 and Daudi cell lines expressed levels of CALLA in the same range as the pre-B ALL cell lines, while the melanoma line A375 was CALLA $^{-}$(data not shown).

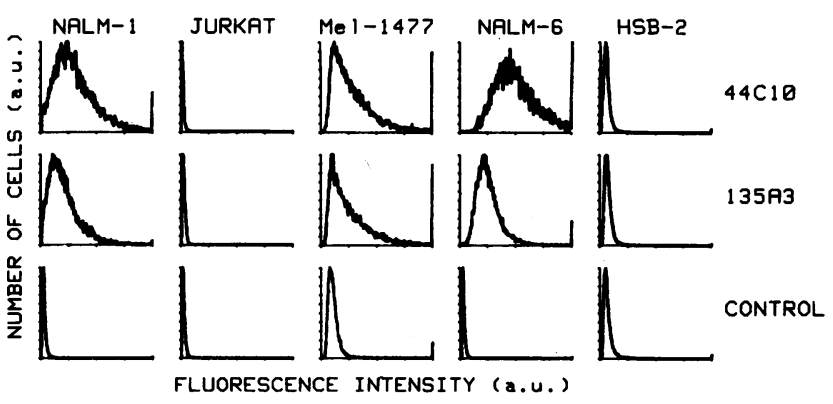

Figure 1. Reactivity of anti-NEP antibody with CALLA ${ }^{+}$cells assessed by flow cytometry. Cells $\left(5-10 \times 10^{5}\right)$ from the NALM-1, NALM-6, Jurkat, HSB-2, and Mel-1477 lines were incubated with saturating levels of MAb $44 \mathrm{C} 10,135 \mathrm{~A} 3$ or control IgG and with FITC-conjugated goat anti-mouse IgG. After three washings in PBS, the cells were analyzed by flow microfluorometry with a FACS II (Becton Dickinson, Mountain View, CA).

Coimmunoprecipitation of NEP and CALLA from leukemia and melanoma cell lines. Both 135A3 (anti-NEP) and 44C10 (anti-CALLA) MAb precipitated a major polypeptide band of apparent $M_{\mathrm{r}} 100,000$ from surface radiolabeled NALM-1 or Mel-1477 cell lines (Fig. 2). This is in agreement with previous data indicating that both CALLA and NEP are glycoproteins with $M_{\mathrm{r}} 90,000-100,000(1,2,4-6,10-12$, $17-19,24-26,30,32,36)$. The amount of antigen reactive with 44C10 MAb was higher in the NALM-1 line than in the Mel-1477 line, consistent with the data shown in Fig. 1. The amount of antigen precipitated by the anti-NEP antibody was less than that observed with anti-CALLA, and contaminating bands were also seen (Fig. 2). This difference is consistent with the lower intensity of staining, even at saturating concentrations, observed with $135 \mathrm{~A} 3 \mathrm{MAb}$ compared to $44 \mathrm{C} 10 \mathrm{MAb}$ (Fig. 1), and is probably due to differences in the avidity of the two MAb towards related epitopes, as indicated by competitive antibody binding studies (data not shown).

Detection of NEP MRNA in lymphoid and melanoma cell lines expressing CALLA on their surface. We probed Northern blots of RNA prepared from various tumor cell lines with a 
NEP cDNA fragment. Cells from the NALM-1, LSD22 and Daudi lines, which are all CALLA ${ }^{+}$, contained major mRNA species of 6 and $3.8 \mathrm{~kb}$ (Fig. 3), in agreement with values reported previously for NALM-6 and other cell types $(14,15)$. The Mel-1477 line, which expressed lower levels of CALLA on its surface (Figs. 1 and 2), also contained less NEP-specific mRNA (Fig. 3). The RNAs prepared from the CALLA ${ }^{-}$lines Jurkat, HSB-2 and A375 did not react with the NEP cDNA probe. In the two CALLA ${ }^{+}$melanoma lines, a minor RNA species of $1.8 \mathrm{~kb}$ was more abundant than in the other cell types.

Demonstration of specific NEP activity in suspensions of CALLA-positive cells and in purified CALLA antigen preparations. We tested lymphoid and melanoma tumor cell suspensions for their ability to hydrolyze the fluorigenic peptide, DAGNPG, a selective substrate for NEP (40). Fig. 4 illustrates that all cell lines expressing CALLA were able to hydrolyze this substrate. The activity could be blocked by more than $90 \%$ by thiorphan or phosphoramidon, two specific inhibitors of NEP. The CALLA ${ }^{-}$lines (Jurkat, A375) had no detectable NEP activity. Thus NEP activity correlates with expression of CALLA at the cell surface.

CALLA antigen purified $\sim 200$-fold from NALM- 6 cells by MAb immunoadsorption was tested for NEP activity. No hydrolysis of the substrate could be detected in the initial experiments. Since $0.05 \mathrm{M}$ diethylamine at $\mathrm{pH} 11.2 \mathrm{had}$ been used for elution of the antigen from the immunoadsorbent, we suspected that demetalization of the enzyme might have occurred. Addition of $50 \mu \mathrm{M} \mathrm{Zn}^{2+}$ did indeed restore enzymatic activity to the preparation. This effect was seen at $\mathrm{Zn}^{2+}$ concentrations between 10 and $500 \mu \mathrm{M}$ (data not shown).

The activity of the purified CALLA preparation (at $\sim 4$ $\mu \mathrm{g} / \mathrm{ml}$ protein, the $\mathrm{V}_{\mathrm{i}}$ was $250 \mathrm{nM} \mathrm{min}^{-1}$ ) was inhibited more than 20 -fold by phosphoramidon and thiorphan at concentrations as low as $1 \mu \mathrm{M}$. The specific activity of the preparation $\left(0.06 \mu \mathrm{mol} \cdot \mathrm{min}^{-1} \cdot \mathrm{mg}^{-1}\right)$ was $\sim 10$-fold less than that reported for purified NEP (40). Since we know that CALLA purified by this rapid affinity procedure can be enriched another 10 -fold by preparative gel electrophoresis, we can conclude that the specific activity of CALLA extracted from a leukemic cell line is of the same order of magnitude as that of NEP extracted from normal kidney.

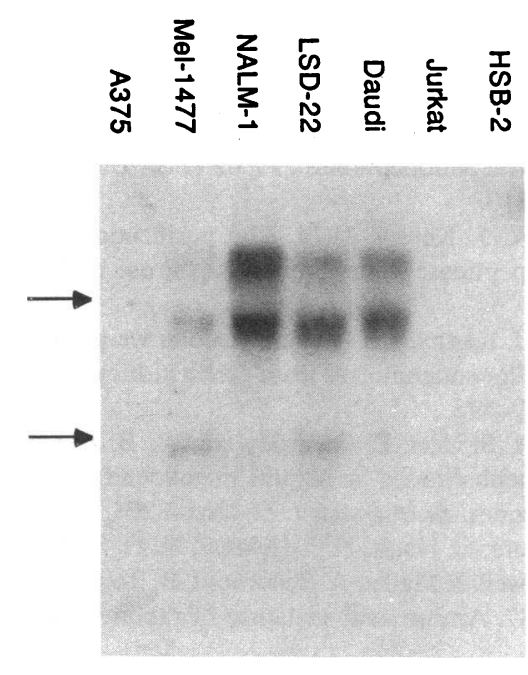

Figure 3. Expression of NEP mRNA in leukemic and melanoma cells. Total cell RNA ( $10 \mu \mathrm{g}$ per lane) was separated in a $1.4 \%$ denaturing agarose gel, transferred to a nylon membrane, and probed with a NEP-specific DNA fragment. The arrows indicate the positions of the $18 \mathrm{~S}$ and 28 S ribosomal RNA bands detected by ethidium bromide staining.

Figure 4. NEP activity in intact pre-B and melanoma cell lines. In three separate experiments (indicated in brackets), cells $\left(2 \times 10^{6}\right)$ were incubated with

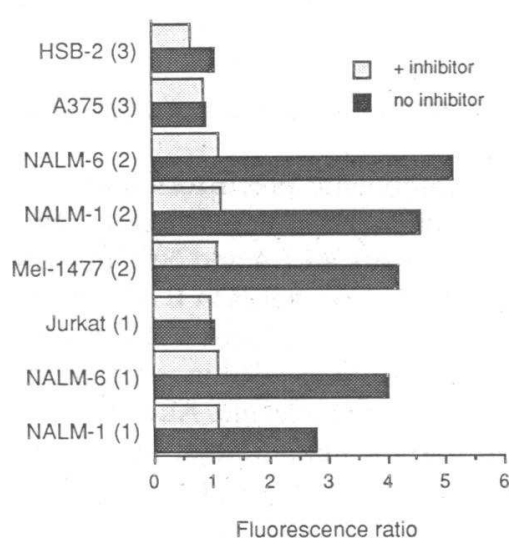

\section{Discussion}

$\mathrm{CALLA}^{+}$cell lines reacted with a MAb produced against rabbit kidney and shown to be specific for neutral endopeptidase. The presence of NEP correlated with the presence of CALLA as determined by flow cytometry (Fig. 1). Coimmunoprecipitation of NEP and CALLA was observed for both a pre-B ALL cell line and a melanoma line (Fig. 2).

The CALLA/NEP antigens precipitated from the pre-B ALL cell line NALM-1 and from the melanoma cell line Mel-1477 had the same apparent $M_{\mathrm{r}}(100,000)$, which corresponds to that reported previously for CALLA precipitated from other pre-B or melanoma cell lines, or from granulocytes and fibroblasts $(4-7,11-13,30)$. The identity of CALLA and NEP is further substantiated by the presence in CALLA ${ }^{+}$leukemia and melanoma cell lines of $\mathrm{mRNA}$ species reactive with a probe specific for human $\operatorname{NEP}(14,16)$. These mRNA species were absent from the two CALLA ${ }^{-}$T-ALL cell lines and from the A375 CALLA ${ }^{-}$melanoma line (Fig. 3). The 6.0 and $3.8 \mathrm{~kb}$ mRNA species have been reported previously in rat brain and kidney (22). They are also present in CALLA ${ }^{+}$human lymphoblastic $(14,15)$ and non-lymphoblastic lines including fibroblasts $(14,15)$ and a colorectal carcinoma line (15), but absent from CALLA $^{-}$lines (15). A third mRNA species $(\sim 1.8$ kb) was more abundant in the melanoma lines than in the leukemic lines tested (Fig. 3). It is unclear whether this has any functional significance.

It is of particular interest that CALLA expressed on the surface of malignant cells has neutral endopeptidase activity. Intact cells hydrolyzed the selective substrate DAGNPG in a reaction that was entirely inhibited by specific inhibitors of NEP. Moreover, in the presence of zinc, CALLA purified by immunoadsorption had a specific activity similar to that of kidney-derived NEP.

NEP is capable of inactivating a wide range of bioactive peptides $(17-19,28,29,31)$. In the nervous system, it plays a central role in the metabolism of neuropeptides (31). It was recently demonstrated that purified NEP can inactivate the $\beta$ form of IL-1, a pleiotropic inflammatory mediator (41). The presence of NEP on reticular cells of pig thymus and lymph 
nodes $(42,43)$ as well as on human granulocytes $(6,29)$ suggests a role for the enzyme in the regulation of inflammatory responses.

The demonstration of an enzymatic activity for CALLA raises several fundamental questions: $(a)$ does the presence of the enzyme at early stages of B cell differentiation imply a function in normal development? $(b)$ does the enzyme play a role in malignancy? $(c)$ does the presence of the enzyme on malignant cells influence the physiological state of cancer patients?

CALLA is present on hemopoietic precursors found in bone marrow and fetal liver, but not on mature B cells $(9,44)$. The demonstration of the identity of CALLA and NEP implies that this enzyme is associated with early stages in B cell ontogeny $(9,44)$. This might be linked to the production of a specific peptide whose expression is transiently needed in maturation, possibly by hydrolysis of a precursor molecule. Alternatively, the appearance of the enzyme on hemopoietic precursors might cause the inactivation of a regulatory peptide and facilitate a differentiation event.

NEP is a member of a large family of zinc-dependent endopeptidases, all of which share a common metal-binding pocket (44a). Other members of this family include the collagenases, whose increased expression is associated with a malignant phenotype $(45,46)$. CALLA is present on malignant cells of diverse origins: common ALL $(1,2,7,8)$, Burkitt's and other poorly differentiated lymphomas $(8,47)$, and tumors of neuroectodermal origin such as melanomas (5) and gliomas (32). It has been demonstrated that ALL cells express CALLA at higher levels than $\mathrm{CALLA}^{+} \mathrm{B}$ cell precursors isolated from normal bone marrow (44). Examination of brain sections from glioma patients (Schreyer, M., unpublished results) suggests that CALLA is found at a higher level in the tumor than in the surrounding normal tissue. Future studies should establish if an increased expression of CALLA/NEP is associated with other tumors, and if this expression has an effect on malignancy.

Many patients with common ALL have elevated amounts of CALLA in their serum $(48,49)$. A reduction of these levels is seen during remission (48). The presence of circulating CALLA, added to the large number of CALLA ${ }^{+}$lymphoblasts, would probably result in high levels of NEP activity in these patients. Since many regulatory peptides can be inactivated by NEP, this could lead to perturbations of their neuroendocrine balance. The potential inactivation of other substrates, such as IL-1, could also have systemic effects.

\section{Acknowledgments}

We would like to thank Pierre Zaech for his assistance with the flow cytometry analysis, and $\mathrm{J}$. Bouvier for his help in setting up the enzymatic assays. We are grateful to J.-C. Cerottini for helpful discussions, for his criticism of the manuscript, and for his enthusiastic support.

This research was supported in part by grants (to M. Letarte) from the National Cancer Institute and the Medical Research Council of Canada. M. Letarte is a Terry Fox Research Scientist.

\section{References}

1. Bernard, A., L. Boumsell, J. Dausset, C. Milstein, and S. F. , Schlossman. 1984. Leukocyte typing. Springer Verlag, Berlin.
2. Ritz, J., J. M. Pesando, J. Notis-McConarty, H. Lazarus, and S. F. Schlossman. 1980. A monoclonal antibody to human acute lymphoblastic leukemia antigen. Nature (Lond.). 283:583-585.

3. Platt, J. L., T. W. LeBien, and A. F. Michael. 1983. Stages of renal ontogenesis identified with monoclonal antibodies reactive with lymphohemopoietic differentiation antigens. J. Exp. Med. 157:155172.

4. Newman, R. A., R. Sutherland, and M. F. Greaves. 1981. The biochemical characterization of a cell surface antigen associated with acute lymphoblastic leukemia and lymphocyte precursors. J. Immunol. 126:2024-2030.

5. Carrel, S., A. Schmidt-Kessen, J. P. Mach, D. Heumann, and C. Girardet. 1983. Expression of common acute lymphoblastic leukemia antigen (CALLA) on human malignant melanoma cells. J. Immunol. 130:2456-2460.

6. McCormack, R. T., R. D. Nelson, and T. W. LeBien. 1986. Structure/function studies of the common acute lymphoblastic leukemia antigen (CALLA/CD10) expressed on human neutrophils. J. Immunol. 137:1075-1082.

7. Greaves, M. F., G. Brown, N. T. Rapson, and T. A. Lister. 1975. Antisera to acute lymphoblastic leukemia cells. Clin. Immunol. Immunopathol. 4:67-84.

8. Foon, K. A., and R. F. Todd. 1986. Immunologic classification of leukemia and lymphoma. Blood. 68:1-31.

9. Hokland, P., P. Rosenthal, J. D. Griffin, L. M. Nadler, J. Daley, M. Hokland, S. F. Schlossmann, and J. Ritz. 1983. Purification and characterization of fetal hematopoietic cells that express the common acute lymphoblastic leukemia antigen (CALLA). J. Exp. Med. 157:114-129.

10. Cossmann, J., L. M. Neckers, W. J. Leonard, and W. R. Greene. 1983. Polymorphonuclear neutrophils express the common lymphoblastic leukemia antigen. J. Exp. Med. 157:1064-1069.

11. Braun, M. P., P. J. Martin, J. A. Ledbetter, and J. A. Hansen. 1983. Granulocytes and cultured human fibroblasts express common lymphoblastic leukemia-associated antigens. Blood. 67:718-725.

12. Metzgar, R. S., M. J. Borowitz, N. H. Jones, and B. R. Dowell. 1981. Distribution of common acute lymphoblastic leukemia antigen in nonhematopoietic tissues. J. Exp. Med. 154: 1249-1254.

13. Quackenbush, E. J., A. Gougos, R. Baumal, and M. Letarte. 1986. Differential localization within human kidney of five membrane proteins expressed on acute lymphoblastic leukemia cells. J. Immunol. 136:118-124.

14. Letarte, M., S. Vera, R. Tran, J. B. L. Addis, R. J. Onizuka, E. J. Quackenbush, C. V. Jongeneel, and R. R. McInnes. 1988. Common acute lymphocytic leukemia antigen is identical to neutral endopeptidase. J. Exp. Med. 168:1247-1253.

15. Shipp, M. A., N. E. Richardson, P. H. Sayre, N. R. Brown, E. L. Masteller, L. K. Clayton, J. Ritz, and E. L. Reinherz. 1988. Molecular cloning of the common acute lymphoblastic leukemia antigen (CALLA) identifies a type II integral membrane protein. Proc. Natl. Acad. Sci. USA. 85:4819-4823.

16. Malfroy, B., W. J. Kuang, P. H. Seeburg, A. J. Mason, and P. R. Schofield. 1988. Molecular cloning and amino acid sequence of human enkephalinase (neutral endopeptidase). FEBS (Fed. Eur. Biochem. Soc.) Lett. 229:206-210.

17. Kerr, M. A., and A. J. Kenny. 1974. The purification and specificity of a neutral endopeptidase from rabbit kidney brush border. Biochem. J. 137:477-488.

18. Kerr, M. A., and A. J. Kenny. 1974. The molecular weight and properties of a neutral metalloendopeptidase from rabbit kidney brush border. Biochem. J. 137:489-495.

19. Gafford, J. T., R. A. Skidgel, E. G. Erdös, and L. B. Hersh. 1983. Human kidney "enkephalinase," a neutral metalloendopeptidase that cleaves active peptides. Biochemistry. 22:3265-3271.

20. Devault, A., C. Lazure, C. Nault, H. Le Moual, N. G. Seidah, M. Chrétien, P. Kahn, J. Powell, J. Mallet, A. Beaumont, B. Roques, P. Crine, and G. Boileau. 1987. Amino acid sequence of rabbit kidney 
neutral endopeptidase 24.11 (enkephalinase) deduced from a complementary DNA. Eur. Mol. Biol. Organ. J. 6:1317-1322.

21. Benchetrit, T., V. Bissery, J. P. Mornon, A. Devault, P. Crine, and B. P. Roques. 1988. Primary structure homologies between two zinc metallopeptidases, the neutral endopeptidase 24.11 ("enkephalinase") and thermolysin, through clustering analysis. Biochemistry. 27: 592-596.

22. Malfroy, B., P. R. Schofield, W. J. Kuang, P. H. Seeburg, A. J. Mason, and W. J. Henzel. 1987. Molecular cloning and amino acid sequence of rat enkephalinase. Biochem. Biophys. Res. Commun. 144:59-66.

23. Ronco, P., H. Pollard, M. Galceran, M. Delauche, J. C. Schwartz, and P. Verroust. 1988. Distribution of enkephalinase (membrane metalloendopeptidase, E. C. 3.4.24.11) in rat organs. Lab. Invest. 58:210-217.

24. Gee, N. S., R. Matsas, and A. J. Kenny. 1983. A monoclonal antibody to kidney endopeptidase-24.11. Biochem. J. 214:377-386.

25. Ronco, P., M. Géniteau, P. Poujeol, C. Melcion, P. Verroust, and A. Vandewalle. 1986. Characterization of monoclonal antibodies to rabbit renal cortical cells. Am. J. Physiol. 250:C506-C516.

26. Tauc, M., F. Châtelet, P. Verroust, A. Vandewalle, P. Poujeol, and P. Ronco. 1988. Characterization of monoclonal antibodies specific for rabbit renal brush border hydrolases: application to immunohistological localization. J. Histochem. Cytochem. 36:523-532.

27. Gee, N. S., N. A. Bowes, P. Buck, and A. J. Kenny. 1985. An immunoradiometric assay for endopeptidase-24.11 shows it to be a widely distributed enzyme in pig tissues. Biochem. J. 228:119-126.

28. Stephenson, S. L., and A. J. Kenny. 1987. The hydrolysis of $\alpha$-human atrial natriuretic peptide by pig kidney microvillar membranes is initiated by endopeptidase-24.11. Biochem. J. 243:183-187.

29. Connelly, J. C., R. A. Skidgel, W. W. Schulz, A. R. Johnson, and E. G. Erdös. 1985. Neutral endopeptidase 24.11 in human neutrophils: cleavage of chemotactic peptide. Proc. Natl. Acad. Sci. USA. 82:8737-8741.

30. Lorkowski, G., J. E. Zijderhand-Bleekemolen, E. G. Erdös, K. von Figura, and A. Hasilik. 1987. Neutral endopeptidase-24.11 (enkephalinase). Biosynthesis and localization in human fibroblasts. Biochem. J. 248:345-350.

31. Matsas, R., A. J. Kenny, and A. J. Turner. 1984. The metabolism of neuropeptides. Biochem. J. 223:433-440.

32. Carrel, S., N. de Tribolet, and N. Gross. 1982. Expression of HLA-DR and common acute lymphoblastic leukemia antigens on glioma cells. Eur. J. Immunol. 12:354-357.

33. Hurwitz, R., J. Hozier, T. LeBien, J. Minowada, K. Gajl-Peczalska, I. Kubonishi, and J. Kersey. 1979. Characterization of a leukemic cell line of the pre-B phenotype. Int. J. Cancer. 23:174-180.

34. Carrel, S., R. S. Accolla, A. L. Carmagnola, and J. P. Mach. 1980. Common human melanoma-associated antigen(s) detected by monoclonal antibodies. Cancer Res. 40:2523-2528.

35. Giuffrè, L., M. Schreyer, J. P. Mach, and S. Carrel. 1988. Cyclic AMP induces differentiation in vitro of human melanoma cells. Cancer (Phila.). 61:1132-1141.
36. Quackenbush, E. J., and M. Letarte. 1985. Identification of several cell surface proteins of non-T, non-B acute lymphoblastic leukemia by using monoclonal antibodies. J. Immunol. 134:1276-1285.

37. Letarte, M., S. Iturbe, and E. J. Quackenbush. 1985. A glycoprotein of molecular weight 85,000 on human cells of B-lineage: detection with a family of monoclonal antibodies. Mol. Immunol. 22:113-124.

38. Carrel, S., S. Salvi, L. Giuffrè, P. Isler, and J.-C. Cerottini. 1987. A novel 90-kDa polypeptide ( $\mathrm{Tp} 90$ ) possibly involved in an antigen-independent pathway of T cell activation. Eur. J. Immunol. 17:835-841.

39. Chomczynski, P., and N. Sacchi. 1987. Single-step method of RNA isolation by acid guanidinium thiocyanate-phenol-chloroform extraction. Anal. Biochem. 162:156-159.

40. Florentin, D., A. Sassi, and B. P. Roques. 1984. A highly sensitive fluorometric assay for "enkephalinase," a neutral metalloendopeptidase that releases tyrosine-glycine-glycine from enkephalins. Anal. Biochem. 141:62-69.

41. Pierart, M. E., T. Najdovski, T. E. Appelboom, and M. M. Deschodt-Lanckman. 1988. Effect of human endopeptidase 24.11 ("enkephalinase") on IL-1-induced thymocyte proliferation assay. $J$. Immunol. 140:3808-3811.

42. Bowes, M. A., and A. J. Kenny. 1986. Endopeptidase-24.11 in pig lymph nodes. Biochem. J. 236:801-810.

43. Bowes, M. A., and A. J. Kenny. 1987. An immunohistochemical study of endopeptidase-24.11 and aminopeptidase $\mathrm{N}$ in lymphoid tissues. Immunology. 60:247-253.

44. Ryan, D. H., C. W. Chapple, S. A. Kossover, A. A. Sandberg, and H. J. Cohen. 1987. Phenotypic similarities and differences between CALLA $^{+}$acute lymphoblastic leukemia cells and normal marrow CALLA ${ }^{+}$B cell precursors. Blood. 70:814-821.

44a. Jongeneel, C. V., J. Bouvier, and A. Bairoch. 1988. FEBS (Fed. Eur. Biochem. Soc.) Lett. In press.

45. Matrisian, L. M., G. T. Bowden, P. Krieg, G. Fürstenberger, J. P. Briand, P. Leroy, and R. Breathnach. 1986. The mRNA coding for the secreted protease transin is expressed more abundantly in malignant than in benign tumors. Proc. Natl. Acad. Sci. USA. 83:94139417.

46. Liotta, L. A., C. N. Rao, and U. M. Wewer. 1986. Biochemical interactions of tumor cells with the basement membrane. Annu. Rev. Biochem. 55:1037-1057.

47. Ritz, J., L. M. Nadler, A. K. Bhan, J. Notis-McConarty, J. M. Pesando, and S. F. Schlossman. 1981. Expression of common acute lymphoblastic leukemia antigen (CALLA) by lymphomas of B-cell and T-cell lineage. Blood. 58:648-652.

48. Carrel, S., F. Buchegger, D. Heumann, C. Girardet, C. Barras, G. Losa, J. P. Mach, and V. von Fliedner. 1984. Detection of the common acute lymphoblastic leukemia antigen in the serum of leukemia patients. J. Clin. Invest. 74:1882-1885.

49. Losa, G. A., D. Heumann, S. Carrel, V. von Fliedner, and J. P. Mach. 1986. Characterization of membrane vesicles circulating in the serum of patients with common acute lymphoblastic leukemia. Lab. Invest. 55:573-579. 